medRxiv preprint doi: https://doi.org/10.1101/2020.01.07.20016857; this version posted January 10, 2020. The copyright holder for this preprint (which was not certified by peer review) is the author/funder, who has granted medRxiv a license to display the preprint in It is made available under a CC-BY-NC 4.0 International license.

\title{
High prevalence of Human Papillomavirus (HPV) type 66 in low-grade cervical lesions of Mexican women
}

Karina Juárez-González ${ }^{1,}{ }^{\dagger}$, Vladimir Paredes-Cervantes ${ }^{2,} \dagger$, Silvia GordilloRodríguez ${ }^{3}$, Saúl González-Guzmán, ${ }^{4,5}$, Xochilt Moncayo-Valencia ${ }^{3}$, Rocío

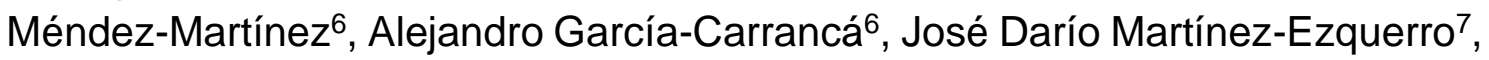
Rodolfo Rivas-Ruiz ${ }^{8}$, Patricia Sánchez-Suárez ${ }^{9}$, Paola Álvarez-Sandoval ${ }^{10}$, Patricia Padilla-Arrieta ${ }^{10}$, Martha Martínez-Salazar ${ }^{11^{*}}$, Salvador Vázquez-Vega ${ }^{12^{*}}$

${ }^{1}$ Unidad de Medicina Familiar No. 28, Instituto Mexicano del Seguro Social (IMSS). ${ }^{2}$ Unidad de Investigación Médica en Inmunología e Infectología, Centro Médico Nacional "La Raza", IMSS. ${ }^{3}$ Hospital de Gineco-Pediatría 3A, IMSS. ${ }^{4}$ Banco Central de Sangre, Centro Médico Nacional "La Raza", IMSS. ${ }^{5}$ Hospital Regional de Alta Especialidad de Zumpango. 'Laboratorio de Virus y Cáncer, Unidad de Investigación Biomédica en Cáncer, Instituto de Investigaciones Biomédicas, Universidad Nacional Autónoma de México \& Instituto Nacional de Cancerología, Secretaría de Salud. ${ }^{7}$ Unidad de Investigación Epidemiológica y en Servicios de Salud, Área Envejecimiento (UIESS-AE), Centro Médico Nacional Siglo XXI, IMSS. ${ }^{8}$ Centro de Adiestramiento en Investigación Clínica, Coordinación de Investigación en Salud. Centro Médico Nacional Siglo XXI, IMSS. 'Unidad de Investigación Médica en Enfermedades Oncológicas. UMAE Oncología, Centro Médico Nacional Siglo XXI, IMSS. ${ }^{10}$ Servicio de Radioterapia, Hospital de Oncología, Centro Médico Nacional Siglo XXI, IMSS. ${ }^{11}$ Unidad de Investigación Médica en Inmunoquímica, UMAE Especialidades, Centro Médico Nacional Siglo XXI, IMSS. ${ }^{12}$ Unidad de Investigación Epidemiológica y en Servicios de Salud (UIESS), Centro Médico Nacional Siglo XXI, IMSS

†Equal contribution

${ }^{*}$ Corresponding authors:

Salvador Vázquez-Vega, Unidad de Investigación Epidemiológica y en Servicios de Salud, CMN Siglo XXI, IMSS. Av. Cuauhtémoc, 330. Col. Doctores Alcaldía Cuauhtémoc. Ciudad de México. CP. 06720. México.

E-mail: salvazvega@gmail.com; Tel.: (52 +55)-56276900 ext. 21072.

Martha Martínez-Salazar, Unidad de Investigación Médica en Inmunoquímica. UMAE Especialidades CMN Siglo XXI, IMSS. Av. Cuauhtémoc, 330. Col. Doctores Alcaldía Cuauhtémoc. Ciudad de México. CP. 06720. México.

E-mail: marthamarsal@gmail.com; Tel.: (52 +55)-56276900 ext. 21476. 
medRxiv preprint doi: https://doi.org/10.1101/2020.01.07.20016857; this version posted January 10,2020 . The copyright holder for this preprint (which was not certified by peer review) is the author/funder, who has granted medRxiv a license to display the preprint in It is made available under a CC-BY-NC 4.0 International license.

\section{Abstract}

Background: HPV-16 infections constitute the highest risk for developing uterine cervix cancer. However, the role of other high-risk types is still controversial.

Objective: To analyze HR-HPV prevalence and its possible associations between HPV and risk factors related to cervical lesions among Mexican women.

Methods: Cross sectional study using 362 cervical samples collected between 2016 and 2017. Fourteen HR-HPV types (16, 18, 31, 33, 35, 39, 45, 51, 52, 56, $58,59,66$ and 68 ) were detected by highly sensitive PCR amplification followed by reverse hybridization. Bivariate and multivariate analyses were performed to investigate the association between HPV types and risk factors among lesions.

Results: Most samples were HR-HPV positive (83.43\%). HPV-16 was the most prevalent infection among negative for intraepithelial lesions or malignancy (78.6\%), high-grade squamous intraepithelial lesions (50\%), and cervical cancer (58.2\%). HPV-66 showed an unexpected high prevalence in atypical squamous cells of undetermined significance (50\%), low-grade squamous intraepithelial $(45.7 \%)$, and only found in $3.6 \%$ of cervical cancers. HPV-16 was significantly prevalent among women between 30-39 years, whereas types 66 and 52 were significantly associated when previously sexually transmitted disease had occurred $(p<0.05)$.

Conclusions: HPV-66 either in single or co-infection with other HR-HPV types (excluding 16 and 18) might be indicative of non-progressive cancer lesions. HPV-66 prevalence was unusually high in low-grade cervical lesions, predominantly in co-infection with HPV-51, and very low among cervical cancer. This should be addressed to interpret results obtained by methods that group type 66 with other HR-types.

\section{Keywords}

HPV 66; prevalence; premalignant cervical lesion; co-infection; HR-HPV; risk factors 
medRxiv preprint doi: https://doi.org/10.1101/2020.01.07.20016857; this version posted January 10,2020 . The copyright holder for this preprint (which was not certified by peer review) is the author/funder, who has granted medRxiv a license to display the preprint in It is made available under a CC-BY-NC 4.0 International license.

\section{Background}

Cervical cancer (CC) is still a major health problem throughout the world, specifically in developing countries. In Mexico, it represents the second cause of death produced by gynecological malignancies [1], where CC has an incidence rate of 23.3 per 100,000 women and a mortality rate of 11.3 per 100,000 women [2]. It is well known that human papillomavirus (HPV) infections are the major sexually transmitted disease and that persistent infections with a set of high-risk HPV (HR-HPV) types constitute the principal etiological agent for developing CC [3]. Among these, HPV types 16, 18, 31, 33, 35, 39, 45, 51, 52, 56, 58, 59, 66, and 68 have been defined as HR-HPVs [4-6], based on their prevalence in cervical cancer, molecular characterization of viral type, and phylogenetic relationships between these viruses $[4,7-9]$. It must be taken into account that prevalence of HPV types, including HPV-66, is dependent on viral detection methods, age of participants, geographical distribution, sample type, among others [10].

HPV-66 was originally detected in a biopsy of a 38 year old patient with a stage I invasive squamous-cell carcinoma of the uterine cervix [11]. Several papers have reported the prevalence of HPV-66 between $4.6-36.5 \%$, predominantly in premalignant lesions $[10,12,13]$. HPV-66 is an $\alpha-P V$ from species 6 and belonging to a third phylogenetic branch unrelated to types 16 and 18 [14]. Indeed, E6 and E7 proteins from type 66 have been shown to degrade p53 and RB cellular proteins, with lower efficiency than other HR-HPV types $[15,16]$.

The aim of this study was to analyze the prevalence and possible associations between HR-HPVs in cervical lesions as well as the risk factors related with HRHPV infections in Mexican women. 
medRxiv preprint doi: https://doi.org/10.1101/2020.01.07.20016857; this version posted January 10,2020 . The copyright holder for this preprint (which was not certified by peer review) is the author/funder, who has granted medRxiv a license to display the preprint in It is made available under a CC-BY-NC 4.0 International license .

\section{Methods}

\subsection{Study design}

This transversal study was realized from March 2016 to February 2017 at the Gynecologic and Pediatric Hospital $3 \mathrm{~A}$ and Oncology Hospital of Instituto Mexicano del Seguro Social (IMSS), Mexico City, with approval number 20143505- 6 by the Ethics Committee. Informed consent signed by each participant, included their authorization for colposcopy, cervical scraping, biopsy sampling, HPV DNA detection and genotyping. The use of clinical data as well as sociodemographic and personal information of each participant was strictly confidential. Women were referred to colposcopy test, if a cervical anomalous result was diagnosed through gynecological examination or cytological test.

\subsection{Patients}

Three hundred and sixty-two women between 15-85 years old were eligible for the study. Data from women with HPV DNA positive test, cytologic diagnosis before colposcopy and complete clinical records were included in the study. Women with incomplete or missing clinical records, inadequate conditions for cervical scraping as menstruation, pregnancy or refusing to participate were not included in this study. The age of participants, age at first intercourse, total number of sexual partners, sexual intercourse without condoms, sexually transmitted diseases records (STD), age at first birth and smoking, were recollected from clinical reports. 
medRxiv preprint doi: https://doi.org/10.1101/2020.01.07.20016857; this version posted January 10,2020 . The copyright holder for this preprint (which was not certified by peer review) is the author/funder, who has granted medRxiv a license to display the preprint in It is made available under a CC-BY-NC 4.0 International license.

\subsection{Obtaining cervical samples and biopsy}

During the gynecological examination, we collected two samples of cervical cells from all participants with cytobrush (both were immersed in two tubes with $2 \mathrm{ml}$ of Preservcyt $\AA^{\circledR}$ ). One cytological samples was used for HPV DNA detection and genotyping and stored at $-20^{\circ} \mathrm{C}$ until analysis. With the other cervical sample, we performed cytological smears and prepared for cytomorphological examination using Papanicolaou staining. In patients with suspected cervical high-grade lesion, a biopsy guided by colposcopy was performed (Colposcope with 50W LED illumination, Labomed Meditech). The biopsy was introduced into a vial with $4 \%$ buffered formalin and labelled with identification data. The colposcopy results were issued by a gynaecologist from the Department of Dysplasia Clinics. While cervical samples were diagnosed by the head of the Pathology Department of the same hospital. All samples were identified by consecutive number, name of participant (coded for confidentiality), grade of cervical lesion, and type of sample.

\subsection{Diagnosis of cervical samples}

Cytologic diagnoses formulated with the Bethesda System 2001 were negative for intraepithelial lesion or malignancy (NILM), atypical squamous cells of undetermined significance (ASCUS), low-grade squamous intraepithelial lesion (LSIL), high-grade squamous intraepithelial lesion (HSIL) and cervical cancer (CC) [17]. Histopathologic diagnoses according to the WHO criteria were: normal cervix (NC), cervical intraepithelial neoplasia grade 1 (CIN 1), cervical intraepithelial neoplasia grades 2, 3 and in situ (CIN 2/CIN 3 and in situ) and cervical cancer (CC) [18]. 
medRxiv preprint doi: https://doi.org/10.1101/2020.01.07.20016857; this version posted January 10,2020 . The copyright holder for this preprint (which was not certified by peer review) is the author/funder, who has granted medRxiv a license to display the preprint in It is made available under a CC-BY-NC 4.0 International license.

The cytological lesions were classified into two main categories:(1) $\leq$ LSIL, that included NILM, ASCUS, and LSIL, and (2) HSIL+, including HSIL and CC. Histological lesions were clustered in $\leq \mathrm{CIN} 1$ (NC and CIN1) and CIN2+ (CIN2, CIN3/in situ and CC).

\subsection{HPV DNA detection and genotyping}

Genomic DNA was extracted from samples using a commercial kit (Wizard® Genomic DNA purification kit protocol, Promega) according to the manufacturer's recommendations. To detect HR-HPV types 16, 18, 31, 33, 35, 39, 45, 51, 52, $56,58,59,66$ and 68 , the purified DNA was then amplified by a strip probe assay [19] for the qualitative detection and identification of 32 genotypes of HPV by detecting specific sequences in the L1 region of the HPV genome grouped in HRHPV, probable high risk (pHR: 26, 53, 70, 73, and 82) and low risk (LR: 6, 11, 40, $42,43,44,54,61,62,67,81,83$, and 89$)$. The genotyping is based on the principle of reverse hybridization. Part of the L1 region (SPF10 region) of HPV genome is amplified with specific primers, and the resulting biotinylated amplicons are denatured and hybridized with specific oligonucleotide probes. Additional primer is added for the amplification of the human HLA-DPB1 gene, to control the quality and extraction of the sample. All probes are immobilized as parallel bands in membrane strips. After hybridization and astringent washing, alkaline phosphatase conjugated with streptavidin is added, which binds to any previously formed biotinylated hybrid (INNO-LiPA HPV Genotyping Extra II Amp kit, Fujirebio) according to the manufacturer's protocol. 
medRxiv preprint doi: https://doi.org/10.1101/2020.01.07.20016857; this version posted January 10,2020 . The copyright holder for this preprint (which was not certified by peer review) is the author/funder, who has granted medRxiv a license to display the preprint in It is made available under a CC-BY-NC 4.0 International license.

\subsection{Statistical analysis}

To calculate the sample size we used single proportion test with a 95\% confidence level [20]. Descriptive statistics were performed to summarize the sociodemographic characteristics of the selected population. In the same way, we estimate the overall HPV prevalence according to the cervical diagnosis. To determine the prevalence of HR-HPV types by cytologic diagnosis, we determined the specific proportion per samples positive to HR-HPV, in addition to cervical samples categories: HPV negative, low risk (LR-HPV), probable high risk (pHR-HPV), and high risk (HR-HPV) HPV infections, as reported previously [4]. The prevalence of HR-HPV in single infection and co-infection in cervical specimens was estimated by chi-squared test. We assessed the association among HR-HPV types according to cervical lesion (OR and $95 \% \mathrm{Cl}$ chi-square test). Finally, to estimate the risk factors associated to the probability of infection by HR-HPV type we carried out bivariate and multivariate analysis adjusted (adOR, $95 \% \mathrm{Cl}$ ) by risk factors: age, age at first intercourse, total number of sexual partners, sexual intercourse without condom, sexually transmitted disease (STD) records, age at first birth, and smoking. All statistical tests were two-sided and considered significant at $p<0.05$. Statistical analysis was performed using commercial and open software (SPSS v25 and R, respectively).

\section{Results}

\subsection{Sociodemographic and clinical characteristics of participants}

Three hundred and sixty-two women met the eligibility criteria for the study. The median age was 40 years old (32-50). Their median age of beginning sexual life 
was 18 years (16-20) and $70 \%$ of them (253/362) have had two or more sexual partners. Of 362 participants 333 (92.0\%) did not use a condom during their sexual relations and $61.0 \%(221 / 362)$ referred the antecedent of STD at some point in their life. The age of first birth in $60.5 \%$ (219/362) was before 19 years of age and $21.3 \%(77 / 362)$ reported smoking history (Table 1$)$.

Table 1. Sociodemographic and clinical characteristics of HPV positive Mexican women $(\mathrm{n}=362)$

\begin{tabular}{lr}
\hline Characteristics & $\mathrm{n}(\%)$ \\
\hline Age (years) & $40(32-50)^{1}$ \\
$\quad \leq 29$ & $73(20.2)$ \\
$30-39$ & $96(26.5)$ \\
$\quad 40-49$ & $90(24.9)$ \\
$\quad \geq 50$ & $103(28.4)$ \\
Age at first intercourse (years) & $18(16-20)^{1}$ \\
$\leq 18$ & $215(59.4)$ \\
$\geq 19$ & $147(40.6)$ \\
Total number of sexual partners & $2(1-3)^{1}$ \\
$\quad 1$ & $109(30.0)$ \\
$\quad \geq 2$ & $253(70.0)$ \\
Sexual intercourse without condom & $333(92.0)$ \\
Sexually transmitted disease (STD) records & $221(61.0)$ \\
Age at first birth & \\
$\quad \leq 19$ & $219(60.5)$ \\
Smoking & $77(21.3)$ \\
\hline 1Median (IQR= Po-25 - Po75). n= Frequency. (\%) = Percentage. & \\
\hline
\end{tabular}

\subsection{HPV prevalence and HR-HPV types according to cervical diagnosis}

In 362 cervical samples, 83.43\% (302/362) were HR-HPV positive, $2.76 \%$ (10/362) were pHR-HPV positive, 4.97\% (18/362) LR-HPV positive, and 8.84\% 
medRxiv preprint doi: https://doi.org/10.1101/2020.01.07.20016857; this version posted January 10,2020 . The copyright holder for this preprint (which was not certified by peer review) is the author/funder, who has granted medRxiv a license to display the preprint in It is made available under a CC-BY-NC 4.0 International license.

(32/362) were HPV negative. In HR-HPV positive cervical samples, type 16 (46.7\%) was the most prevalent, followed by types 66 (32.8\%), 51 (31.8\%), 52 (31.1\%), $58(20.2 \%), 59(17.2 \%)$, and $56(11.3 \%)$. Viral types with an overall prevalence lower than 10\% were 18 (9.9\%), 39 (8.3\%), 45 (7.6\%), 31 (5-0\%), 68 (1.0\%), $35(1.0 \%)$, and $33(0.7 \%)$ (Figure 1).

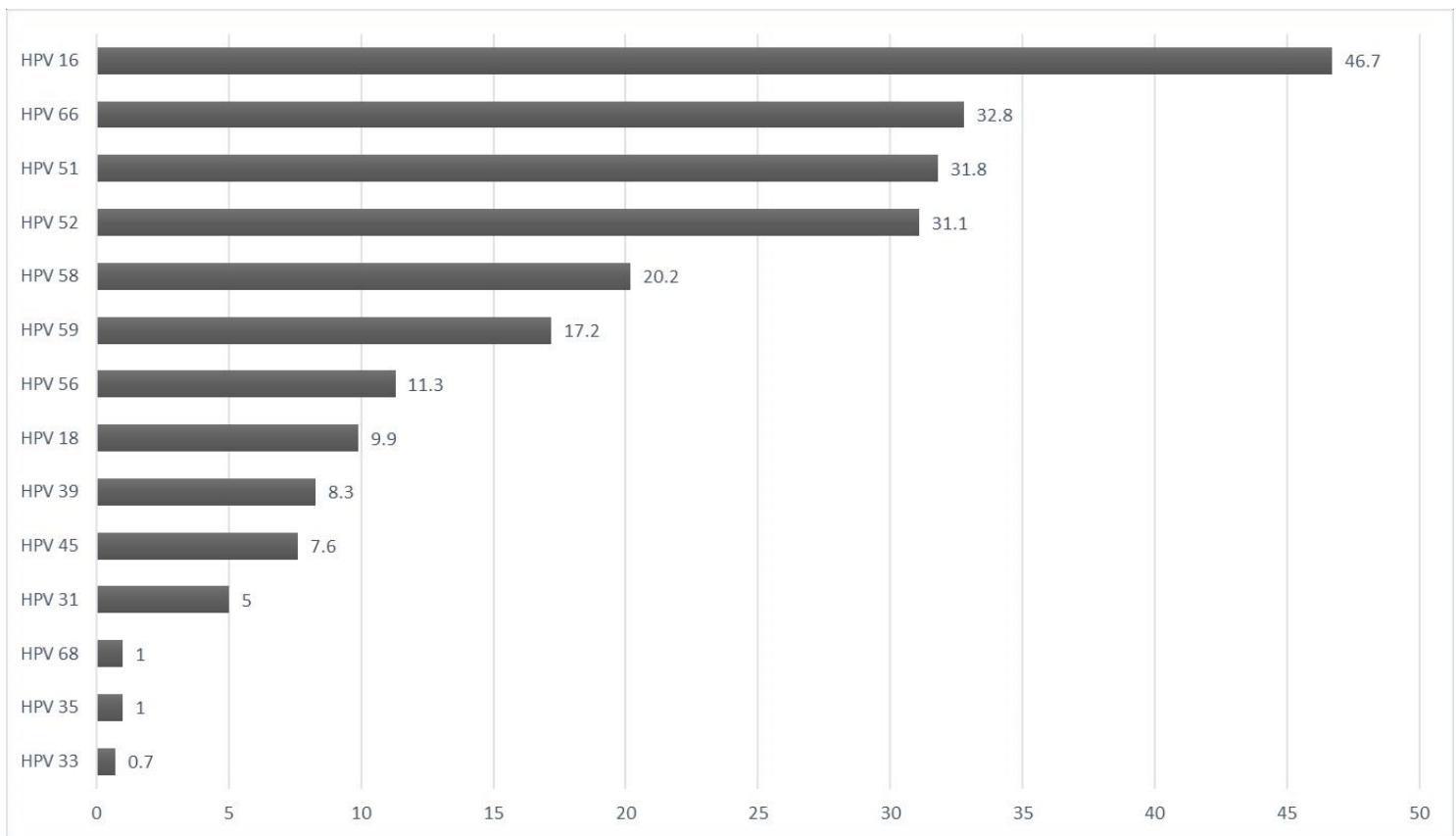

Figure 1. Prevalence of HPV types in positive cervical samples from Mexican women $(n=302)$. The percentage values are shown

Cytological diagnosis included NILM (28, 9.3\%), ASC-US (62, 20.5\%), LSIL (105, 34.8\%), HSIL (52, 17.2\%), and CC (55, 18.20\%). Two HPV types were the most prevalent analyzed by cytological diagnosis. HPV-16 had high prevalence in NILM, HSIL, and CC (78.6\%, 50\% and 58.2\%, respectively), followed by HPV-66 in ASC-US and LSIL premalignant lesions ( $50 \%$ and $45.7 \%$, respectively), and very low in CC (3.2\%). In contrast, types 52 and 51 had approximately similar prevalence from NILM to HSIL, decreasing in CC. HPV-18 was present only in NILM and CC (25\% and 14.5\%, respectively). HPVs 45, 58 and 59 had 
medRxiv preprint doi: https://doi.org/10.1101/2020.01.07.20016857; this version posted January 10, 2020. The copyright holder for this preprint (which was not certified by peer review) is the author/funder, who has granted medRxiv a license to display the preprint in

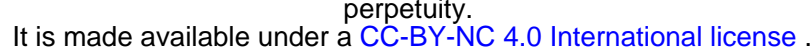

heterogeneous prevalence among cytological categories. Finally, HPVs 31, 33, $35,39,56$, and 68 had low prevalence and were absent in some cervical cytological categories. HPVs 51, 52, and 66 infections were predominantly observed among LSIL and ASC-US while HPV-16 was present in high percentages particularly in NILM and in CC (Figure 2).

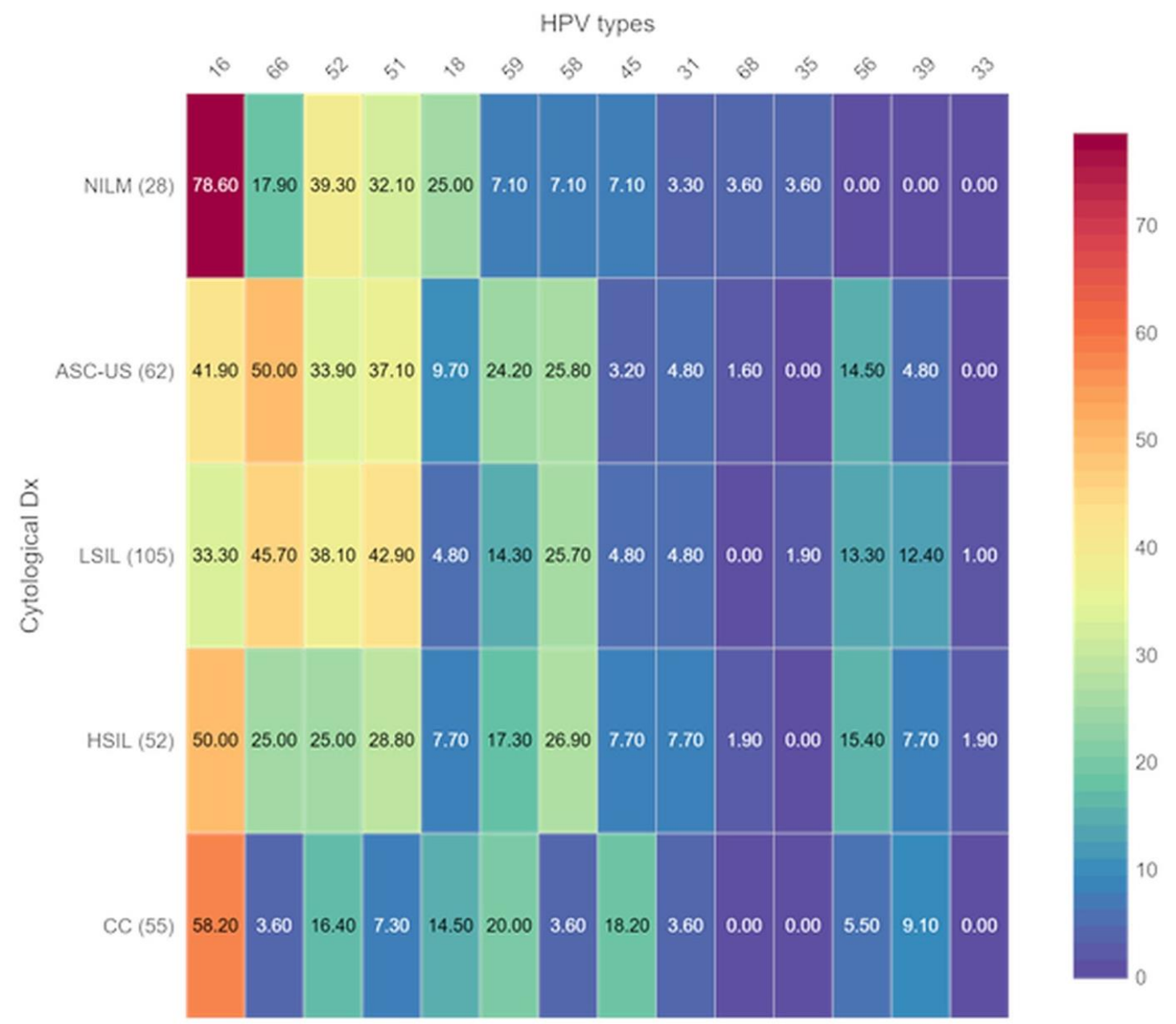

Figure 2. HR-HPV types according to cytologic diagnosis. The heatmap shows the prevalence in percentages between high-risk HPV types and diagnosis according to Bethesda classification. A color gradient is shown (right). Dx, diagnosis; NILM, negative for intraepithelial lesion or malignancy; ASC-US, atypical squamous cells of undetermined significance; LSIL, low-grade squamous intraepithelial lesion; HSIL, high-grade squamous intraepithelial lesion; CC, cervical cancer; human papillomavirus; HR-HPV, high risk HPV 
medRxiv preprint doi: https://doi.org/10.1101/2020.01.07.20016857; this version posted January 10,2020 . The copyright holder for this preprint (which was not certified by peer review) is the author/funder, who has granted medRxiv a license to display the preprint in It is made available under a CC-BY-NC 4.0 International license .

\subsection{HR-HPV prevalence in single and co-infection in cervical lesions}

Of 302 cervical smears positive to HR-HPV, 38.4\% (116/302) had single infection and $61.6 \%$ (186/302) had co-infection ( $\geq 2$ HR-HPV types).

The most prevalent single infections involved HPV-16 (31.0\%), followed by 52 (12.9\%), 66 and 51 (10.3\%, in both). Prevalence less than $10 \%$ was observed in HPV 39, 45 (7.8\%, in both), 58 (5.2\%), 18, 31, 56, and HPV 59 (3.4\%, all), and 35 (0.9\%). HPV 33 and 68 were absent. We performed a bivariate analysis (chisquare test, $\mathrm{p}<0.05)$, regardless of whether it was single or co-infection, and observed that specifically HPV-66 was associated to ASC-US $(\mathrm{OR}=4.6,95 \% \mathrm{lC}=$ 1.55-13.65, $\mathrm{p}<0.05)$ and LSIL $(O R=3.87,95 \% I C=1.36-10.96)$. Regardless of the HR-HPV type, single infection was statistically significant in CC status (OR=2.70, $95 \% \mathrm{Cl}=1.06-6.89, \mathrm{p}<0.05)$, and in $\mathrm{HSIL}+(\mathrm{OR}=2.18,95 \% \mathrm{Cl}=1.34-3.54, \mathrm{p}<0.05)$. The most frequent HR-HPV co-infections involved HPV 66-51 (28.49\%), HPV 1652 (25.80\%), HPV 16-51 (23.65\%), and HPV 16-66 (22.58\%); other co-infections were below $20 \%$. However, only two HR-HPV co-infections were significantly associated when assessing the probability of association $\left(X^{2}\right.$ test, $\left.p<0.05\right)$ : HPV $66-51(\mathrm{OR}=3.41,95 \% \mathrm{Cl}=1.86-6.26, \mathrm{p}<0.05)$ and HPV 52-58 $(\mathrm{OR}=2.48,95 \% \mathrm{Cl}=$ 1.30-4.73, $p<0.05)$.

\subsection{Associations among HR-HPVs according to cervical lesion}

We found several significant associations (chi-square test, $p<0.05$ ) between HRHPV and cervical lesions. In LSIL, HPV 52-58 (OR= 4.04, 95\% $\mathrm{Cl}=1.4-11.64, \mathrm{p}<$ $0.05)$ and HPV 66-51 (OR= 3.96, $95 \% \mathrm{Cl}=1.48-10.61, \mathrm{p}<0.05)$ were significantly associated, while HPV 16-52 $(\mathrm{OR}=7.87,95 \% \mathrm{Cl}=1.35-45.83, \mathrm{p}<0.05)$ and HPV 66-51 $(\mathrm{OR}=7.5,95 \% \mathrm{Cl}=1.49-37.65, \mathrm{p}<0.05)$ were in HSIL. When we analyzed 
HR-HPV risk infection by $\leq$ LSIL and HSIL+ categories, our results showed that in $\leq$ LSIL, HPV 66-51 and HPV 52-58 had a statistically significant association $(\mathrm{OR}=2.818,95 \% \mathrm{Cl}=1.388-5.720, \mathrm{p}<0.05$ and $\mathrm{OR}=2.412,95 \% \mathrm{Cl}=1.126-5.169, \mathrm{p}<$ 0.05, respectively). Whereas in HSIL+, HPV 66-51 had a statistically significant association $(\mathrm{OR}=5.22,95 \% \mathrm{Cl}=1.411-19.31, \mathrm{p}<0.05)$. Results according to the histopathological diagnosis of samples were similar to cytologic diagnosis (Data not shown).

\subsection{Probability of HR-HPV infection and risk factors associated}

In order to assess the HR-HPV risk infection by risk factors, we performed several bivariate and logistic regression models adjusted by the following risk factors (adOR, $95 \% \mathrm{Cl})$ : age, age at first intercourse, total number of sexual partners, sexual intercourse without condom, sexually transmitted disease (STD) records, age at first birth, and smoking. We found that HPV-16 risk infection was statistically significant in women at 30-39 years old $(\mathrm{adOR}=2.104,95 \% \mathrm{Cl}=1.09$ 4.07, $p<0.05)$. Conversely, the risk of infection with types 66 and 52 was statistically significant in women with STDs records $(\operatorname{adOR}=2.02,95 \% \mathrm{Cl}=1.19$ 3.43, $\mathrm{p}<0.05$, adOR= 1.69, $95 \% \mathrm{Cl}=1.01-2.85, \mathrm{p}<0.05$, respectively) (Figure 3).

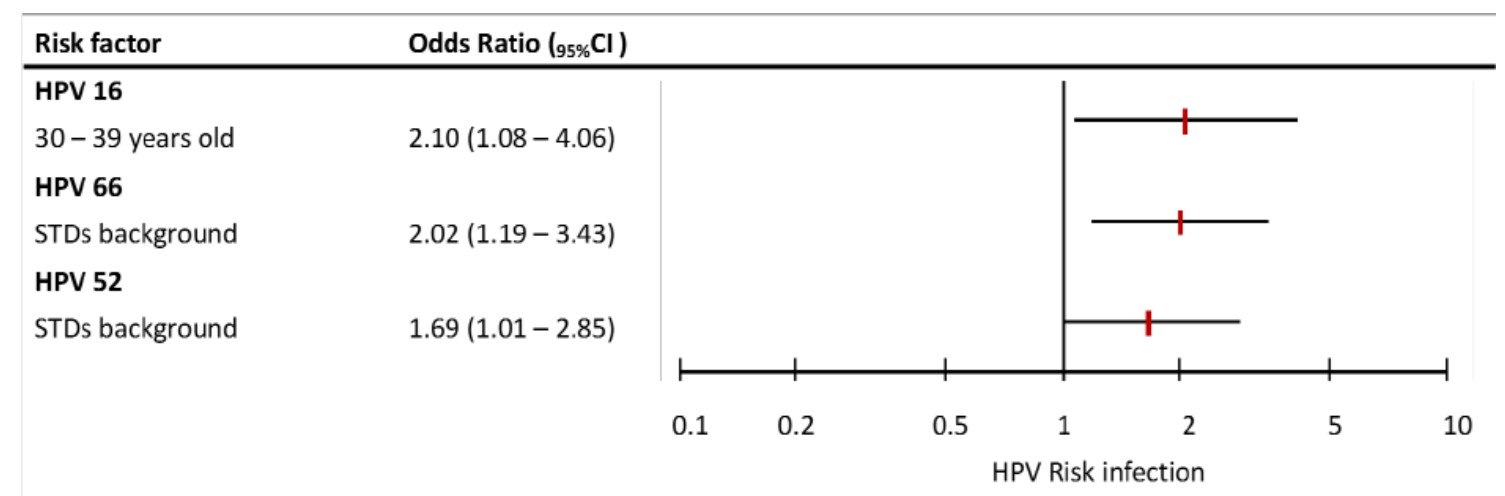

Figure 3. Risk factors associated with HPV infection in cervical samples of women referred to dysplasia clinics. Odds ratios adjusted (adOR) and 95\% confidence 
medRxiv preprint doi: https://doi.org/10.1101/2020.01.07.20016857; this version posted January 10, 2020. The copyright holder for this preprint (which was not certified by peer review) is the author/funder, who has granted medRxiv a license to display the preprint in It is made available under a CC-BY-NC 4.0 International license.

interval $(95 \% \mathrm{Cl})$ for risk factors: age, age at first intercourse, total number of sexual partners, sexual intercourse without condom, sexually transmitted disease -STDrecords, age at first birth, smoking. Only those HR-HPV and risk factors that had statistical significance for each logistic regression model are presented.

\section{Discussion}

In this cross-sectional study in Mexican women, we were able to identify 14 highrisk oncogenic HPV types in $83.43 \%$ of participants (302/364 abnormal cervical smears). Their sociodemographic characteristics were similar to those of previous studies [12,13,21]. However, HR-HPV overall prevalence (83.43\%) was mildly higher in our study compared to previous reports such as those from Ortega Cervantes et al. (2016) [22] and Flores Miramontes et al. (2015) [23], with $82.0 \%$ and $71.24 \%$, respectively. Our results showed that HPV-16 was the most frequent type (46.7\%). Surprisingly, our study also showed a high prevalence of HPV-66 (32.8\%), in contrast to other reports in which this type had a very low incidence ( 5\%) [3]. According to Chouhy D. et al. (2013) [24] these results might be a consequence of the detection methods employed such as capturing hybrids that do not include HPV-66 or COBAS HPV test that detects it not specifically, but within a pool that includes other HR-HPVs [25,26]. Additionally, misidentifying this type by confusing it with type 56, such as with the linear array system [24]. In more recent reports using similar molecular techniques to detect HPV types, a higher prevalence of HPV-66 has been observed than in previous reports $[12,13,21]$

Also, other studies with HIV+ women and abnormal cytology reported high prevalence of HPV-66 (12.0\% [27] and 32.3\% [28]). Although, we did not have information concerning their immunological status of our participants, we had data of STD records and $60 \%$ of our study population had a history of STD. These 
medRxiv preprint doi: https://doi.org/10.1101/2020.01.07.20016857; this version posted January 10,2020 . The copyright holder for this preprint (which was not certified by peer review) is the author/funder, who has granted medRxiv a license to display the preprint in It is made available under a CC-BY-NC 4.0 International license .

set of diseases have been previously shown to be associated with HPV infection [29]; and in addition, we observed that STD was significantly associated with HPV types 52 and 66 infections.

HPV types such as $18,51,52,58$, and 59 showed similar prevalences to those previously reported in other studies in Mexican women [30,31]. Conversely, HPVs 31, 33, and 35, showed a lower prevalence than other studies from Mexico $[32,33]$. The differences observed in our study may be explained by geographical and regional HPV variations [34]. Besides, we should consider the effect of the migratory phenomenon that can cause an increase in the prevalence of other HPV genotypes [35].

In several studies HPV-66 has been detected in single infection, however other reports observed this viral type mainly in co-infection $[21,34,36,37]$. We found both situations in our study: co-infection and single infection in a 2:1 ratio. Regarding cervical lesion grade, HPV-66 presence was more important in ASCUS and LSIL ( $\leq$ LSIL) than in CC (HSIL+), which is in agreement with previous reports $[37,38]$. In co-infection events, HPV-66 had a statistically significant association with HPV-51 ( $p<0.05)$, surprisingly not with HPV-16 ( $p>0.05)$, even though is the most prevalent type in HPV infections.

Given these observations, in combination with previous studies where the contribution of HPV-66 to premalignant and malignant lesions of the uterine cervix was evaluated $[39,40]$, HPV-66 infection might indicate a non-progressive to cervical cancer phenotype.

Regarding the risk factors analyzed, we agree that those associated with sexual activity were important for the acquisition of HR-HPV [5,41], in particular STD records. In this sense, despite sexually transmitted disease records were 
medRxiv preprint doi: https://doi.org/10.1101/2020.01.07.20016857; this version posted January 10,2020 . The copyright holder for this preprint (which was not certified by peer review) is the author/funder, who has granted medRxiv a license to display the preprint in It is made available under a CC-BY-NC 4.0 International license .

obtained through clinical files and the type of pathogen or infection was not specified, this limitation of our study might also be considered as a proposal for future research. A strength of our study was that the calculation of the sample size made it possible to obtain statistically reliable results regarding the real frequency of HPV-66 in Mexican women.

Finally, our evidence supports the notion that HPV-66 should not be considered as a high-risk type, since we found it predominantly in premalignant lesions and non-malignant samples. Additional studies are required to determine the real contribution of HPV-66 in cervical carcinogenesis and whether or not HPV-66 infection might indicate a non-progressive to cervical cancer phenotype.

\section{Conclusions}

HPV-66 prevalence was unusually high in low-grade cervical lesions, predominantly in co-infection with HPV-51, and very low frequency in cervical cancer. This information should be taken into consideration for the interpretation of results obtained with methods that do not include or group type 66 with other HR-types. Finally, the presence of HPV-66 either in single or co-infections with other HR-HPV types, excluding 16 and 18 may, indicate lesions that will not progress to cancer. HPV-66 infection might be more frequent than previously thought, and specific genotyping may clarify these observations.

\section{Competing interest}

The authors declare no conflicts of interest. 


\section{Contribution of the authors}

Equal contribution $\uparrow=J G, P C$.

Study conception and design: JG, PC, ME, MS, VV.

Acquisition of data: JG, PC, GR, GG, MV, MM, GC, ME, RR, SS, AS, PA, MS, VV.

Analysis of data: JG, PC, GG, GC, ME, RR, VV.

Interpretation of data: JG, PC, GG, MM, GC, ME, MS, VV.

Writing the article: JG, PC, GR, MV, ME, RR, SS, MS, VV.

Critical revision of the article: GR, GG, MV, MM, GC, ME, RR, SS, AS, PA, MS, VV.

Final approval of the article: JG, PC, GR, GG, MV, MM, GC, ME, RR, SS, AS, PA, MS, VV.

JG= Juárez González

$\mathrm{PC}=$ Paredes Cervantes

GR= Gordillo Rodríguez

GG= González Guzmán

$\mathrm{MV}=$ Moncayo Valencia

MM= Méndez Martínez

GC= García Carrancá

$\mathrm{ME}=$ Martínez Ezquerro

RR= Rivas Ruíz

SS= Sánchez Suárez

AS= Alvarez Sandoval

$\mathrm{PA}=$ Padilla Arrieta

MS= Martínez Salazar

VV= Vázquez Vega 
medRxiv preprint doi: https://doi.org/10.1101/2020.01.07.20016857; this version posted January 10, 2020. The copyright holder for this preprint (which was not certified by peer review) is the author/funder, who has granted medRxiv a license to display the preprint in It is made available under a CC-BY-NC 4.0 International license.

\section{Acknowledgements}

This project was supported by CONACyT Sectoral Funds (FOSISS) SALUD2014-C01-234198. PROT/FIS/IMSS 1377. To the team of Cellular Pathology and Molecular Cancer Laboratory, UIMEO HO. CMN SXXI, IMSS.

This work was partially supported by a grant to AG-C from PAPIIT-UNAM (IN213016).

Manuscript Writing Training Team (CEMAI 2019-2) of CONACyT for their reviews and constructive criticism of this research paper.

\section{References}

[1] J. Ferlay, M. Ervik, F. Lam, M. Colombet, L. Mery, M. Piñeros, A. Znaor, I. Soerjomataram, F. Bray, Global Cancer Observatory: Cancer Today, Lyon, France: International Agency for Research on Cancer. (2018). http://gco.iarc.fr/today/home (accessed October 29, 2019).

[2] Secretaría de Salud, Información estadística - Estadísticas de cáncer de mama y cáncer cérvico uterino, Programa de Acción Específico Prevención Y Control Del Cáncer de La Mujer 2013 - 2018. (2015). http://www.gob.mx/salud/acciones-y-programas/informacion-estadistica (accessed October 29, 2019).

[3] L. Bruni, G. Albero, B. Serrano, M. Mena, D. Gómez, J. Muñoz, F.X. Bosch, S. de Sanjosé, Human papillomavirus and related diseases report, ICO/IARC Information Centre on HPV and Cancer (HPV Information Centre). (2019). https://www.hpvcentre.net/statistics/reports/XWX.pdf (accessed October 29, 2019).

[4] M. Arbyn, M. Tommasino, C. Depuydt, J. Dillner, Are 20 human papillomavirus types causing cervical cancer?, The Journal of Pathology. 234 (2014) 431-435. https://doi.org/10.1002/path.4424.

[5] IARC Working Group on the Evaluation of Carcinogenic Risks to Humans, Biological agents. Volume 100 B. A review of human carcinogens, IARC 
Monogr. Eval. Carcinog. Risks Hum. 100 (2012) 1-441.

[6] D. Bzhalava, C. Eklund, J. Dillner, International standardization and classification of human papillomavirus types, Virology. 476 (2015) 341-344.

[7] N. Muñoz, F.X. Bosch, S. de Sanjosé, R. Herrero, X. Castellsagué, K.V. Shah, P.J.F. Snijders, C.J.L.M. Meijer, International Agency for Research on Cancer Multicenter Cervical Cancer Study Group, Epidemiologic classification of human papillomavirus types associated with cervical cancer, N. Engl. J. Med. 348 (2003) 518-527.

[8] E.-M. de Villiers, C. Fauquet, T.R. Broker, H.-U. Bernard, H. zur Hausen, Classification of papillomaviruses, Virology. 324 (2004) 17-27.

[9] V. Cogliano, R. Baan, K. Straif, Y. Grosse, B. Secretan, F.E. Ghissassi, Carcinogenicity of human papillomaviruses, Lancet Oncol. 6 (2005) 204.

[10]I.G.S.S. Serra, E.D. Araujo, G.S. Barros, F.L.S.G. Santos, R.Q. Gurgel, M.V.A. Batista, Prevalence of human papillomavirus types associated with cervical lesions in Sergipe state, Northeastern Brazil: high frequency of a possibly carcinogenic type, Epidemiol. Infect. 146 (2018) 1184-1193.

[11] A.R. Tawheed, S. Beaudenon, M. Favre, G. Orth, Characterization of human papillomavirus type 66 from an invasive carcinoma of the uterine cervix, J. Clin. Microbiol. 29 (1991) 2656-2660.

[12] R.A. Ouedraogo, T.M. Zohoncon, S.P. Guigma, I.M.A. Traore, A.K. Ouattara, M. Ouedraogo, F.W. Djigma, D. Obiri-Yeboah, C. Ouedraogo, J. Simpore, Oncogenic human papillomavirus infection and genotypes characterization among sexually active women in Tenkodogo at Burkina Faso, West Africa, $\begin{array}{llll}\text { Papillomavirus } & \text { Research. } & 6 & \text { (2018) }\end{array}$ https://doi.org/10.1016/j.pvr.2018.09.001.

[13] F. Martora, M.E. Della Pepa, E. Grimaldi, G. Franci, V. Folliero, A. Petrillo, M.T. Schettino, P. De Franciscis, M. Galdiero, M. Galdiero, Seven years prevalence and distribution of high and low risk HPV genotypes in women living in the metropolitan area of Naples, Cancer Epidemiol. 63 (2019) 101625.

[14]Z. Chen, L.B. de Freitas, R.D. Burk, Evolution and Classification of Oncogenic Human Papillomavirus Types and Variants Associated with Cervical Cancer, in: D. Keppler, A.W. Lin (Eds.), Cervical Cancer, Springer New York, New York, NY, 2015: pp. 3-26. 
[15] T. Hiller, Comparative Analysis of 19 Genital Human Papillomavirus Types with Regard to p53 Degradation, Immortalization, Phylogeny, and Epidemiologic Risk Classification, Cancer Epidemiol. Biomarkers Prev. 15 (2006) 1262-1267.

[16] M. Mansour, M. Touka, U. Hasan, A. Bellopede, A. Smet, R. Accardi, A.-S. Gabet, B.S. Sylla, M. Tommasino, E7 properties of mucosal human papillomavirus types 26, 53 and 66 correlate with their intermediate risk for cervical cancer development, Virology. 367 (2007) 1-9.

[17]D. Solomon, D. Davey, R. Kurman, A. Moriarty, D. O'Connor, M. Prey, S. Raab, M. Sherman, D. Wilbur, T. Wright, The 2001 Bethesda System: Terminology for Reporting Results of Cervical Cytology, Obstetrical \& Gynecological Survey. $\quad 57 \quad$ (2002) 505-507. https://doi.org/10.1097/00006254-200208000-00015.

[18] World Health Organization, WHO | Guidelines for screening and treatment of precancerous lesions for cervical cancer prevention, (2013). http://www.who.int/reproductivehealth/publications/cancers/screening_and_ treatment_of_precancerous_lesions/en/ (accessed October 29, 2019).

[19] L. Xu, E. Padalko, A. Oštrbenk, M. Poljak, M. Arbyn, Clinical Evaluation of INNO-LiPA HPV Genotyping EXTRA II Assay Using the VALGENT Framework, IJMS. 19 (2018) 2704.

[20]J.O. Talavera, R. Rivas-Ruiz, L.P. Bernal-Rosales, [Clinical research V. Sample size], Rev Med Inst Mex Seguro Soc. 49 (2011) 517-522.

[21]J. Monsonego, G. Pollini, M.J. Evrard, P. Sednaoui, L. Monfort, D. Quinzat, R. Dachez, K. Syrjänen, Linear array genotyping and hybrid capture II assay in detecting human papillomavirus genotypes in women referred for colposcopy due to abnormal Papanicolaou smear, International Journal of STD \& AIDS. 19 (2008) 385-392. https://doi.org/10.1258/ijsa.2007.007259.

[22] L. Ortega-Cervantes, A. Aguilar-Lemarroy, A.E. Rojas-García, Human Papilloma Virus Genotypes in Women from Nayarit, Mexico with Squamous Intraepithelial Lesions and Cervical Cancer, International Journal of Health Sciences. 10 (2016) 309-320. https://doi.org/10.12816/0048727.

[23]M.G. Flores-Miramontes, L.A. Torres-Reyes, L. Alvarado-Ruíz, S.A. Romero-Martínez, V. Ramírez-Rodríguez, L.M.A. Balderas-Peña, V. VallejoRuíz, P. Piña-Sánchez, E.I. Cortés-Gutiérrez, L.F. Jave-Suárez, A. Aguilar- 
Lemarroy, Human papillomavirus genotyping by Linear Array and NextGeneration Sequencing in cervical samples from Western Mexico, Virology Journal. 12 (2015). https://doi.org/10.1186/s12985-015-0391-4.

[24]D. Chouhy, R.M. D’Andrea, M. Iglesias, A. Messina, J.J. Ivancovich, B. Cerda, D. Galimberti, H. Bottai, A.A. Giri, Prevalence of human papillomavirus infection in Argentinean women attending two different hospitals prior to the implementation of the National Vaccination Program, J. Med. Virol. 85 (2013) 655-666.

[25] M. Saville, F. Sultana, M.J. Malloy, L.S. Velentzis, M. Caruana, E.L.O. Ip, M.H.T. Keung, K. Canfell, J.M.L. Brotherton, D. Hawkes, Clinical Validation of the cobas HPV Test on the cobas 6800 System for the Purpose of Cervical Screening, J. Clin. Microbiol. 57 (2018) 516.

[26] D.A. Cook, W. Mei, L.W. Smith, D.J. van Niekerk, K. Ceballos, E.L. Franco, A.J. Coldman, G.S. Ogilvie, M. Krajden, Comparison of the Roche cobas $\AA$ 4800 and Digene Hybrid Capture® 2 HPV tests for primary cervical cancer screening in the HPV FOCAL trial, BMC Cancer. 15 (2015) 12.

[27] J.A.M. Dols, G. Reid, R. Kort, F.H.J. Schuren, H. Tempelman, T.R. Bontekoe, H. Korporaal, E.M. Van der Veer, P.W. Smit, M.E. Boon, PCR-based identification of eight lactobacillus species and $18 \mathrm{hr}-\mathrm{HPV}$ genotypes in fixed cervical samples of south african women at risk of HIV and BV, Diagn. Cytopathol. 40 (2012) 472-477.

[28] M.F. Teixeira, M. Sabidó, A.L. Leturiondo, C. de Oliveira Ferreira, K.L. Torres, A.S. Benzaken, High risk human papillomavirus prevalence and genotype distribution among women infected with HIV in Manaus, Amazonas, Virol. J. 15 (2018) 69.

[29] H.-S. Kim, T.J. Kim, I.-H. Lee, S.R. Hong, Associations between sexually transmitted infections, high-risk human papillomavirus infection, and abnormal cervical Pap smear results in OB/GYN outpatients, J. Gynecol. Oncol. 27 (2016). https://doi.org/10.3802/jgo.2016.27.e49.

[30] A. Aguilar-Lemarroy, V. Vallejo-Ruiz, E.I. Cortés-Gutiérrez, M.E. SalgadoBernabé, N.P. Ramos-González, L. Ortega-Cervantes, R. Arias-Flores, I.M. Medina-Díaz, F. Hernández-Garza, G. Santos-López, P. Piña-Sánchez, On behalf of the IMSS Research Network on HPV, Human papillomavirus infections in Mexican women with normal cytology, precancerous lesions, 
and cervical cancer: Type-specific prevalence and HPV coinfections, Journal of Medical Virology. 87 (2015) 871-884. https://doi.org/10.1002/jmv.24099.

[31] M. Salcedo, P. Pina-Sanchez, V. Vallejo-Ruiz, A. Monroy-Garcia, A. AguilarLemarroy, E.I. Cortes-Gutierrez, G. Santos-Lopez, H. Montoya-Fuentes, R. Grijalva, V. Madrid-Marina, T. Apresa-Garcia, D.M. Hernandez, L.F. JaveSuarez, P. Romero, A. Poot, E. Salgado, P. Ramos-Gonzalez, R. GonzalezHernandez, J.C. Canton, L. Jimenez-Aranda, M. Parra-Melquiadez, L. Paniagua, M. Mendoza, H. Arreola, V. Villegas, K. Torres-Poveda, M. Bahena-Roman, B. Gonzalez-Yebra, K. Taniguchi, C. Rodea, A. MantillaMorales, M.L. Mora-Garcia, C.K. Velazquez-Velazquez, C. CordovaUscanga, R. Peralta, R. Lopez-Romero, D. Marrero, C. Bandala, J. ReyesLeyva, M.E. Furuya, E. Almeida, M.E. Galvan, I. Grijalva, Human Papillomavirus Genotypes among Females in Mexico: a Study from the Mexican Institute for Social Security, Asian Pac. J. Cancer Prev. 15 (2015) 10061-10066.

[32] R. DelaRosa-Martínez, M. Sánchez-Garza, R. López-Revilla, HPV genotype distribution and anomalous association of HPV33 to cervical neoplastic lesions in San Luis Potosí, Mexico, Infect. Agent. Cancer. 11 (2016) s208.

[33] R. López-Revilla, L.A. Martínez-Contreras, M. Sánchez-Garza, Prevalence of high-risk human papillomavirus types in Mexican women with cervical intraepithelial neoplasia and invasive carcinoma, Infectious Agents and Cancer. 3 (2008). https://doi.org/10.1186/1750-9378-3-3.

[34] P. Guan, R. Howell-Jones, N. Li, L. Bruni, S. de Sanjosé, S. Franceschi, G.M. Clifford, Human papillomavirus types in 115,789 HPV-positive women: a meta-analysis from cervical infection to cancer, Int. J. Cancer. 131 (2012) 2349-2359.

[35] E.M. Kojic, L. Conley, T. Bush, S. Cu-Uvin, E.R. Unger, K. Henry, J. Hammer, G. Escota, T.M. Darragh, J.M. Palefsky, J.T. Brooks, P. Patel, Prevalence and Incidence of Anal and Cervical High-Risk Human Papillomavirus (HPV) Types Covered by Current HPV Vaccines Among HIV-Infected Women in the SUN Study, J. Infect. Dis. 217 (2018) 1544-1552.

[36] A. Nielsen, T. Iftner, C. Munk, S.K. Kjaer, Acquisition of High-Risk Human Papillomavirus Infection in a Population-Based Cohort of Danish Women, Sexually Transmitted Diseases. $36 \quad$ (2009) 609-615. 
https://doi.org/10.1097/olq.0b013e3181a96d0e.

[37] C. Pannier-Stockman, C. Segard, S. Bennamar, J. Gondry, J. -C. Boulanger, H. Sevestre, S. Castelain, G. Duverlie, Prevalence of HPV genotypes determined by PCR and DNA sequencing in cervical specimens from French women with or without abnormalities, Journal of Clinical Virology. 42 (2008) 353-360. https://doi.org/10.1016/j.jcv.2008.03.022.

[38] T. Sasagawa, W. Basha, H. Yamazaki, M. Inoue, High-risk and multiple human papillomavirus infections associated with cervical abnormalities in Japanese women, Cancer Epidemiol. Biomarkers Prev. 10 (2001) 45-52.

[39] K.M. Elfström, V. Smelov, A.L.V. Johansson, C. Eklund, P. Naucler, L. Arnheim-Dahlström, J. Dillner, Long-term HPV type-specific risks for ASCUS and LSIL: A 14-year follow-up of a randomized primary HPV screening trial: Long-Term HPV Type-Specific Risks for ASCUS/LSIL, Int. J. Cancer. 136 (2015) 350-359.

[40] V. Smelov, K.M. Elfström, A.L.V. Johansson, C. Eklund, P. Naucler, L. Arnheim-Dahlström, J. Dillner, Long-term HPV type-specific risks of highgrade cervical intraepithelial lesions: A 14-year follow-up of a randomized primary HPV screening trial: Long-term HPV type-specific risks for HSIL, Int. J. Cancer. 136 (2015) 1171-1180.

[41] J.M. Deacon, C.D. Evans, R. Yule, M. Desai, W. Binns, C. Taylor, J. Peto, Sexual behaviour and smoking as determinants of cervical HPV infection and of CIN3 among those infected: a case-control study nested within the Manchester cohort, Br. J. Cancer. 83 (2000) 1565-1572. 